Article

\title{
Design and Synthesis of Anti-MRSA Benzimidazolylbenzene- sulfonamides. QSAR Studies for Prediction of Antibacterial Activity
}

\section{Marco Martín González-Chávez ${ }^{1,2, *}$, Francisco Méndez ${ }^{3}$, Roberto Martínez ${ }^{4}$, Cuaúhtemoc Pérez-González ${ }^{5}$ and Fidel Martínez-Gutiérrez ${ }^{2}$}

1 Programa de Doctorado en Ciencias Biológicas, Universidad Autónoma Metropolitana, México D.F., Mexico

2 Facultad de Ciencias Químicas-CIEP, Universidad Autónoma de San Luis Potosí, San Luis Potosí, SLP, Mexico

3 Departamento de Química, División de Ciencias Básicas e Ingeniería, Universidad Autónoma Metropolitana, Unidad Iztapalapa, México D.F., Mexico

4 Instituto de Química, Universidad Nacional Autónoma de México, México D. F, Mexico

5 Departamento de Sistemas Biológicos, Universidad Autónoma Metropolitana, Unidad Xochimilco, México D. F., Mexico

* Author to whom correspondence should be addressed; E-Mail: gcmm@uaslp.mx; Tel.: +52 444826 2440; Fax: +52 4448262372 .

Received: 22 November 2010; in revised form: 24 December 2010 / Accepted: 28 December 2010 / Published: 29 December 2010

\begin{abstract}
A series of benzimidazolylbenzenesulfonamide compounds containing electronreleasing and electron-withdrawing substituents were synthesized and tested for their in vitro antibacterial activity. Two BZS compounds showed strong antibacterial activity against methicillin-resistant Staphylococcus aureus and Bacillus subtilis. Quantitative studies of their structure-activity relationship using a simple linear regression analysis were applied to explore the correlation between the biological activity and the charges on acidic hydrogen atoms in the synthesized compounds.
\end{abstract}

Keywords: benzimidazole; sulphonamide; MRSA; antibacterial activity 


\section{Introduction}

Drug resistance in Gram-positive bacteria is a worldwide public health problem with serious morbidity and mortality consequences. For example, the incidence of penicillin-resistant Streptococcus pneumoniae continues to increase worldwide, except in cities that apply good antibiotic use policies. An additional problem is the emergence of multi-drug resistant strains in America, Europe and Asia [1-3], for example, vancomycin resistance in Enterococcus. These infections have emerged as severe complications, mainly in critically ill patients in tertiary care hospital wards [4,5]. Staphylococcus aureus is one of the most prominent and widespread human pathogens, causing skin and tissue infections, deep abscess formation, pneumonia, endocarditis, osteomyelitis, toxic shock syndrome and bacteremia. Methicillin-resistant Staphylococcus aureus (MRSA) has been recognized as one of the main pathogenic causes of nosocomial infections throughout the world [6,7]. Infections caused by MRSA are a problem in health care institutions in the United States and worldwide, especially for intensive care unit patients [8]. Solving the problem of drug resistance will depend partially on the development of chemotherapeutic agents that selectively attack new bacterial targets.

Some benzimidazoles $[9,11]$ and sulphonamides [12,13] have recently presented promising antimicrobial activities. Benzimidazolylbenzenesulfonamides show a variety of pharmacological activities due to their affinity toward various cellular protein targets or enzyme inhibitors, such as the peptide-like thrombin inhibitor [14], NR2B-selective $N$-methyl-D-aspartate antagonists [15], inhibitors of the enzyme $11 \beta$-hydroxysteroid dehydrogenate [16], and the human immunodeficiency virus type I integrase inhibitor [17].

Benzimidazolylbenzenesulfonamide (BZS) compounds fulfill the structural requirements for affinity toward metalloproteinases: a ligand group that may be directed toward a metal center, a sulfonamide group that may provide a hydrogen bonding interaction with the amino acids of the enzyme backbone, and an aryl group that may have effective Van der Waals interactions with enzyme subsites (Figure 1). Based on these considerations, we have focused on the synthesis of novel BZS compounds in search of synthetic chemotherapeutic agents.

Figure 1. Design of BZS derivatives and the structure-activity relationships considered in this study.

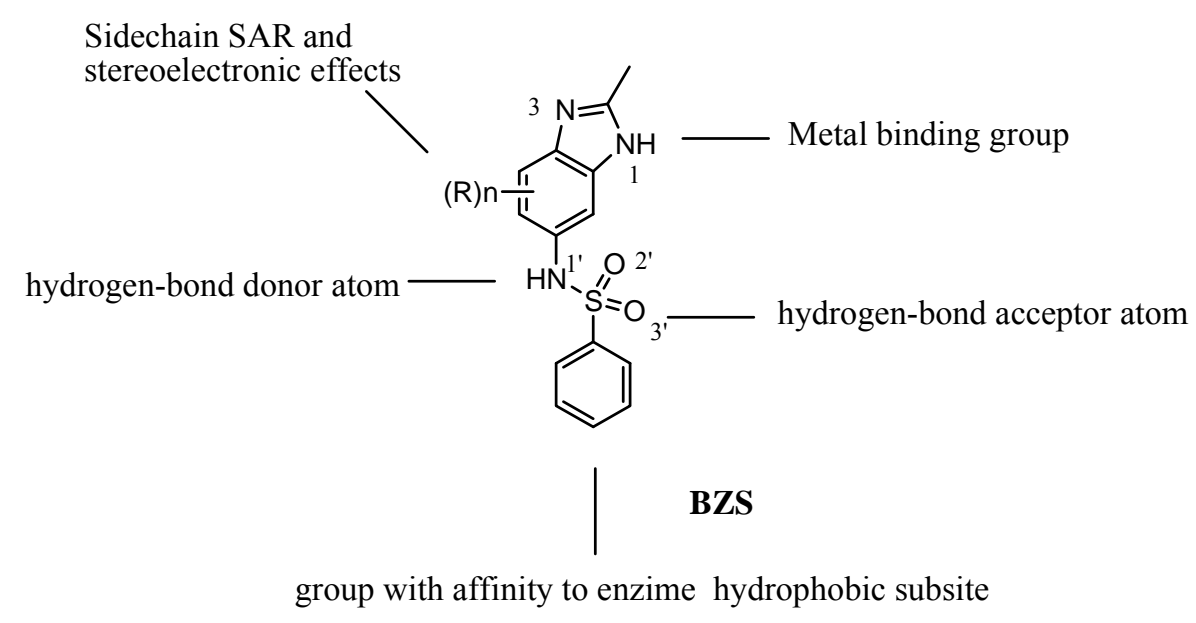


The present work establishes the regio-chemical, stereo-chemical, and electronic requirements of the benzimidazole ring of BZS for achieving activity toward Gram-positive bacteria, such as MRSA. The electronic requirements are modulated by the presence (or absence) of electron-releasing or electron-withdrawing substituents at positions 4,5 and 7 of the benzimidazole ring of novel BZS derivatives.

\subsection{Chemistry}

BZS compounds are usually obtained via benzimidazolamines. The synthesis of benzimidazolamines 10-13 proceeded from the corresponding $R_{3}$-dinitroaniline compounds 1-4. The formation of the imidazole ring was carried out by reductive cyclization with acetic acid and tin (II) chloride dihydrate at reflux temperature, followed by acid hydrolysis in the presence of $10 \%$ hydrochloric acid at reflux temperature. The primary amine of benzimidazolamine $\mathbf{1 4}$ was obtained by nitration of benzimidazole 8 using a mixture of nitric and sulfuric acids, followed by reduction with tin (II) chloride dihydrate in hydro-chloric acid at reflux temperature. Synthesis of benzimidazolamine 15 proceeded from the starting material nitroaniline 5 . The second nitro group necessary for formation of the imidazole ring was obtained by nitration of 5 with fuming nitric acid. Formation of the imidazole ring was done by reductive cyclization, similar to the procedure for formation of the imidazole ring in derivatives 10-13. Finally, the benzimidazolamine 15 was obtained by acid hydrolysis of the amide group (Scheme 1).

Scheme 1. Synthesis of the benzimidazolamines 10-15.

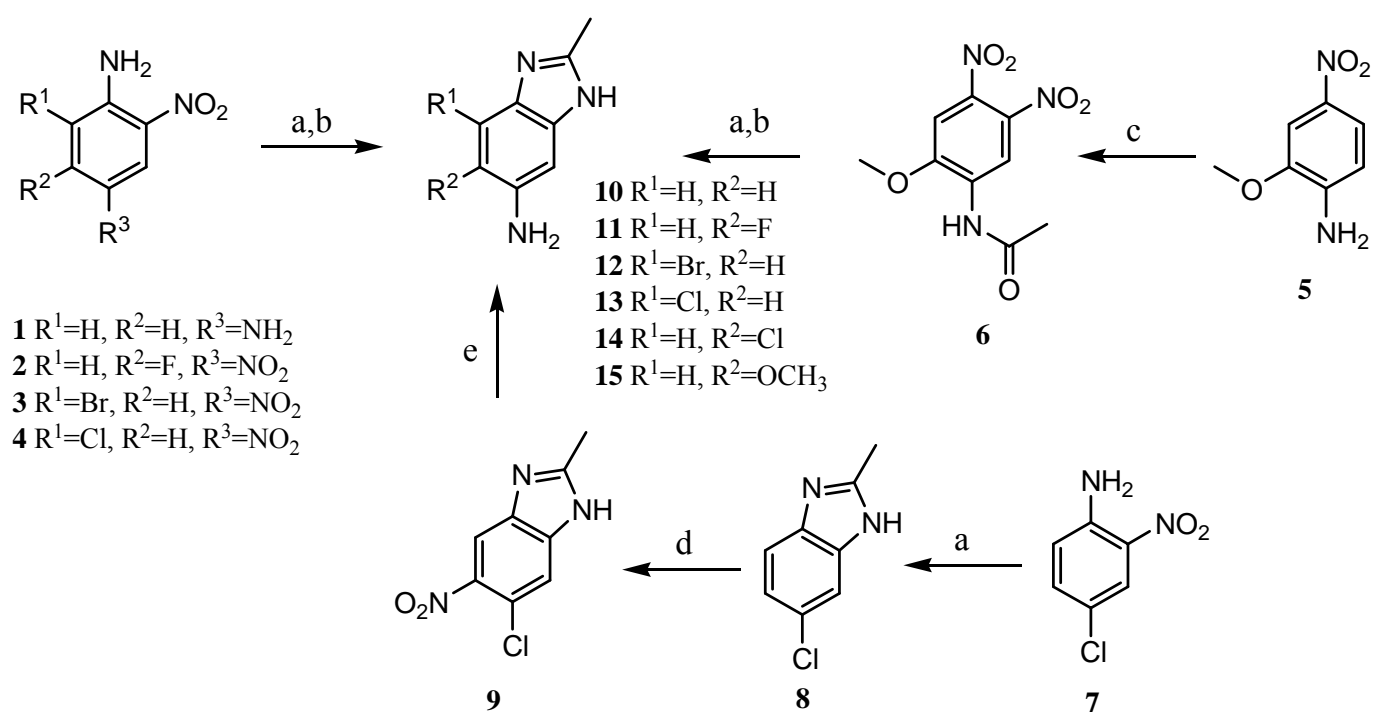

Reagents and conditions: (a) $\mathrm{SnCl}_{2} 2 \mathrm{H}_{2} \mathrm{O} / \mathrm{CH}_{3} \mathrm{CO}_{2} \mathrm{H}$, reflux; (b) $10 \% \mathrm{HCl}$, reflux; (c) fuming $\mathrm{HNO}_{3}, 0-5{ }^{\circ} \mathrm{C}$; (d) $\mathrm{H}_{2} \mathrm{SO}_{4} / \mathrm{HNO}_{3}, \mathrm{RT}$; (e) $\mathrm{SnCl}_{2} 2 \mathrm{H}_{2} \mathrm{O} / \mathrm{HCl}$, reflux.

The BZS 16-21 were obtained by reaction of benzimidazolamines 10-15 with benzenesulfonyl chloride in the presence of pyridine as a base and acetone as a solvent under $\mathrm{N}_{2}$ atmosphere, at room temperature for $24 \mathrm{~h}$. Benzimidazolamines are bidentate nucleophiles, and produced the BZS 
derivatives 22 y 23 (Scheme 2). This type of products was not obtained after of purification when the benzimidazole ring contained a halogen atom.

Scheme 2. Synthesis of the BZS 16-23.

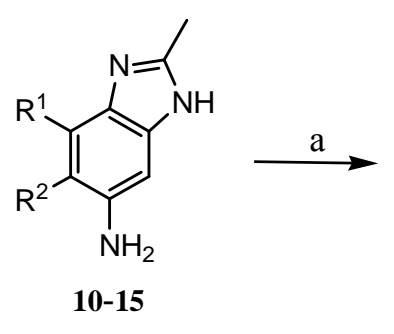<smiles>[R]c1c(NS(=O)(=O)c2ccccc2)cc2[nH]c(C)nc2c1[R]</smiles><smiles>[R]C[R]([R])([H])[R]([H])([H])[R]([H])([H])[R]([H])([H])[R]([H])([H])[H]</smiles>
$19 \mathrm{R}^{1}=\mathrm{Cl}, \mathrm{R}^{2}=\mathrm{H}$ $20 \mathrm{R}^{1}=\mathrm{H}, \mathrm{R}^{2}=\mathrm{Cl}$ $21 \mathrm{R}^{1}=\mathrm{H}, \mathrm{R}^{2}=\mathrm{OCH}_{3}$

Reagents and conditions: (a) $\mathrm{C}_{6} \mathrm{H}_{5} \mathrm{SO}_{2} \mathrm{Cl} /$ pyridine, acetone, $24 \mathrm{~h} \mathrm{RT}$.

The derivatives of BZS that contained nitro groups, i.e., 24 and 26-31, were obtained from their 1621 precursors via nitration with fuming nitric acid. Only one mononitrated product was obtained in all cases, with the exception of derivative 16. The BZS derivative containing an amino group were obtained by reduction of the nitro group of $\mathbf{2 4}$ using tin (II) chloride dihydrate in a 1:1 ethyl acetate/ethanol mixture (Scheme 3).

Compounds 10-26 were purified by column chromatography on silica gel using ethyl acetate/ hexane as the eluent. Compounds 27-31 did not require chromatographic purification.

Scheme 3. Synthesis of the BZSs 24-31.
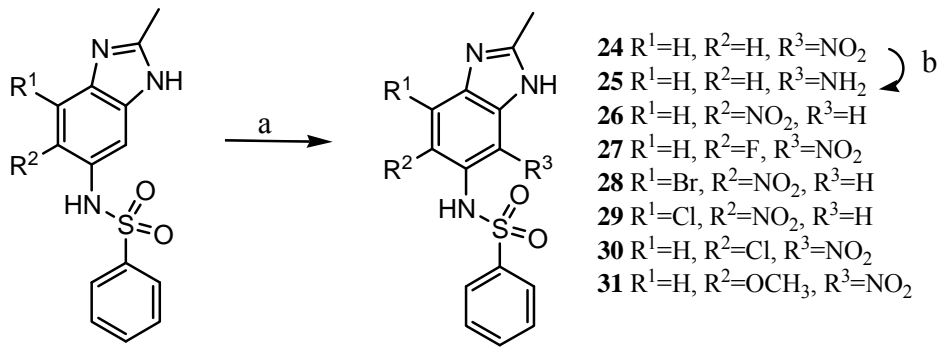

16-21

Reagents and conditions: (a) fuming $\mathrm{HNO}_{3}, 0-5^{\circ} \mathrm{C}, 1 \mathrm{~h}$; (b) $\mathrm{SnCl}_{2} 2 \mathrm{H}_{2} \mathrm{O}$, AcOEt/EtOH 1:1, reflux.

\subsection{Microbiology}

\subsubsection{Microbial strains and culture media}

The Gram-positive microorganisms Bacillus subtilis (ATCC 6051), Staphylococcus aureus (ATCC 25923), methicillin-resistant S. aureus (MRSA) (ATCC 43300) and Enterococcus fecalis (ATCC 29212) were assayed. All microorganisms were grown in brain hear infusion (BHI) broth (BD, CA). Solid media was obtained by adding $1.5 \%(\mathrm{w} / \mathrm{v})$ agar to the liquid media. 


\subsubsection{Antibacterial activity}

The antimicrobial activity of the synthesized compounds was determined on 96-well microdilution plates according to the protocols (published by the Clinical and Laboratory Standards Institute [18]) for determining the minimum inhibitory concentration (MIC) of each compound that results in inhibition of bacterial growth. Disposable micro titration plates were used for the antimicrobial tests. All compounds were dissolved in ethanol and diluted 2-512 times with $100 \mu \mathrm{L}$ of Mueller-Hinton and bacteria were inoculated at a concentration of $10^{5}$ colony forming units ( $\mathrm{CFU} \mathrm{mL}{ }^{-1}$ ). The MIC was measured after $20 \mathrm{~h}$ incubation at $37^{\circ} \mathrm{C}$ with each substance tested. Growth inhibition of the bacterial strains was assessed by visual inspection. The antibacterial activities of the synthesized compounds were compared to oxacillin and ciprofloxacin as positive control. All assays were carried out in triplicate.

\subsection{Theoretical calculations}

Quantum chemical calculations of BZS 16-31 in the gas phase were performed using GAUSSIAN 03 [19] in conjunction with density functional theory (DFT). An extensive search for the lowest energy conformer on the potential energy surfaces of the BZS compounds was carried out at the B3LYP/3$21 \mathrm{G}(\mathrm{d})$ level, and geometry optimization of the lowest energy BZS conformer, followed by frequency calculations, was performed at the B3LYP/6-31G+(d,p) level. The atomic charges were obtained from a Mulliken population analysis. A simple linear regression analysis was performed using the StatGraphics Plus statistical software package.

\section{Results and Discussion}

All of the BZS compounds described above have not been previously reported. The structures of all synthesized compounds were confirmed by spectral data, and the IR, ${ }^{1} \mathrm{H}-\mathrm{NMR}$, and mass spectra agreed with the proposed structures.

The synthesized compounds 16-31 were tested in vitro against four Gram-positive bacteria using a standard microdilution method and the control drugs (oxacillin and ciprofloxacin), as shown in Tables 1 and 2. The results reported in Table 1 indicate that compounds 16-23 inhibited growth of the screened microorganisms, yielding MIC values in the range 125-500 $\mu \mathrm{g} / \mathrm{mL}$. However, the synthesized compounds exhibited low antibacterial potencies.

Table1. MIC ( $\mu \mathrm{g} / \mathrm{mL})$ values for BZS compounds 16-23.

\begin{tabular}{ccccc}
\hline Compounds & $\begin{array}{c}\text { S. aureus } \\
\text { ATCC 25923 }\end{array}$ & $\begin{array}{c}\text { MRSA } \\
\text { ATCC 43300 }\end{array}$ & $\begin{array}{c}\text { E. fecalis } \\
\text { ATCC 29212 }\end{array}$ & $\begin{array}{c}\text { B. subtilis } \\
\text { ATCC 6633 }\end{array}$ \\
\hline $\mathbf{1 6}$ & $>500$ & 500 & 250 & 500 \\
$\mathbf{1 7}$ & 500 & 500 & 125 & 500 \\
$\mathbf{1 8}$ & $>500$ & 500 & 250 & $>500$ \\
$\mathbf{1 9}$ & 500 & 500 & 250 & $>500$ \\
$\mathbf{2 0}$ & 500 & 500 & 125 & 500 \\
$\mathbf{2 1}$ & $>500$ & $>500$ & 250 & 500 \\
$\mathbf{2 2}$ & 500 & 500 & 250 & 375 \\
$\mathbf{2 3}$ & $>500$ & $>500$ & 500 & $>500$ \\
\hline
\end{tabular}


Table 2 reveals that the compounds 24-31 showed antibacterial activity against $S$. aureus, MRSA, E. fecalis and B. subtilis with MIC values in the range $2-500 \mu \mathrm{g} / \mathrm{mL}$.

Table 2. MIC $(\mu \mathrm{g} / \mathrm{mL})$ values for BZS compounds 24-31.

\begin{tabular}{lcccc}
\hline Compounds & $\begin{array}{c}\text { S. aureus } \\
\text { ATCC 25923 }\end{array}$ & $\begin{array}{c}\text { MRSA } \\
\text { ATCC 43300 }\end{array}$ & $\begin{array}{c}\text { E. fecalis } \\
\text { ATCC 29212 }\end{array}$ & $\begin{array}{c}\text { B. subtilis } \\
\text { ATCC 6633 }\end{array}$ \\
\hline $\mathbf{2 4}$ & 187 & 187 & 125 & 8 \\
$\mathbf{2 5}$ & $>500$ & $>500$ & 250 & 500 \\
$\mathbf{2 6}$ & 187 & 125 & 250 & 8 \\
$\mathbf{2 7}$ & $>500$ & 500 & 500 & 86 \\
$\mathbf{2 8}$ & 16 & 10 & 125 & 2 \\
$\mathbf{2 9}$ & 31 & 18 & 125 & 2 \\
$\mathbf{3 0}$ & 500 & 500 & 500 & 86 \\
$\mathbf{3 1}$ & $>500$ & 500 & 500 & 78 \\
Oxacillin & 0.25 & 2 & 8 & $>125$ \\
Ciprofloxacin & $1 \mu \mathrm{g} / \mathrm{mL}$ & $\leq 0.25 \mu \mathrm{g} / \mathrm{mL}$ & $1 \mu \mathrm{g} / \mathrm{mL}$ & $\leq 0.25 \mu \mathrm{g} / \mathrm{mL}$ \\
\hline
\end{tabular}

The structure-activity relationship (SAR) of compounds 16-31 was determined using the data presented in Tables 1 and 2. SAR studies revealed that the presence of an electron-withdrawing group on the benzimidazole ring increased the antimicrobial activity, and activity decreased in the presence of electron-releasing atoms or groups. Specifically, compounds with a nitro group in either position 5 or position 7 of the benzimidazole core significantly increased potency against $S$. aureus, MRSA and B. subtilis. The dependence of compounds efficacy (biological activity) on the position of the nitro group did not appear to be important. The transformation of the nitro group in position 7 to an amino group led to loss of antibacterial activity. The substitution and region of a third atom or group in the nitro-BZS was decisive for increasing activity in MRSA and B. subtilis. The highest result antibacterial activity was exhibited by BZS containing a nitro group at position 5 and either chlorine or bromine atoms at position 4 of the benzimidazole ring. The importance of nitro group in enhancing the antimicrobial activity against Gram-positive bacteria is supported by similar results observed by Ören et al. [20] and Moro et al. [21] Exchange of the groups or atoms in the benzimidazole ring did not strongly inhibit the growth of $E$. fecalis.

The SAR study suggested that the acidity of hydrogens 1 and 1 ' in the BZS molecule plays an important role in activity of against Gram-positive bacteria. Romero and Mendez showed that the charge on the hydrogen atom, calculated using DFT, is indicative of the gas phase acidity of substituted phenols, in agreement with the local hard and soft acids-bases principle (HSAB).[22]

Based on this antecedent and with the purpose of quantifying a substituent's effect on antibacterial activity, a study was carried out to investigate the quantitative structure-activity relationship (QSAR) by linear regression analysis of the $-\log \mathrm{MIC}(\mu \mathrm{M})$ as a function of the charge on acidic hydrogen atoms and on BZS hydrogen bond acceptors.

The charge on hydrogen atoms $(\mathrm{qH})$ that were hydrogen-bonded to the nitrogen atoms of BZS, as determined from the energetically favorable conformers of each BZS structure at the B3LYP/6$31+\mathrm{G}(\mathrm{d}, \mathrm{p})$ level, showed a larger charge for compounds containing $\mathrm{Cl}$ or $\mathrm{Br}$ atoms at position 4 and a nitro group at position 5 (Table 3) of the benzimidazole. These two compounds presented higher activities against MRSA and $B$. subtilis. The main differences between the conformations of BZS and with a $\mathrm{NO}_{2}$ group lay in the orientation of the $\mathrm{NHSO}_{2}$ hydrogen atom with respect to the $\mathrm{NO}_{2}$ group. 
Table 3. CMI and atomic charges on substituent atoms of BZS.

\begin{tabular}{llllllll}
\hline \multirow{2}{*}{ BZS } & $\begin{array}{l}\text { B. subtilis } \\
\text { MIC }(\boldsymbol{\mu M})\end{array}$ & $\begin{array}{c}\text { MRSA } \\
\text { MIC }(\boldsymbol{\mu M})\end{array}$ & q H1 & q N3 & q H1’ & q O2’ & \multirow{2}{*}{ q O3’ } \\
\hline $\mathbf{1 6}$ & 1740 & 1740 & 0.304 & -0.317 & 0.324 & -0.533 & -0.528 \\
$\mathbf{1 7}$ & 1639 & 1639 & 0.305 & -0.315 & 0.334 & -0.530 & -0.532 \\
$\mathbf{1 8}$ & - & 1365 & 0.308 & -0.267 & 0.326 & -0.523 & -0.530 \\
$\mathbf{1 9}$ & - & 1554 & 0.308 & -0.302 & 0.325 & -0.522 & -0.529 \\
$\mathbf{2 0}$ & 1554 & 1554 & 0.305 & -0.321 & 0.320 & -0.516 & -0.526 \\
$\mathbf{2 1}$ & 1575 & - & 0.301 & -0.325 & 0.345 & -0.531 & -0.528 \\
$\mathbf{2 4}$ & 24 & 562 & 0.335 & -0.321 & 0.382 & -0.489 & -0.467 \\
$\mathbf{2 5}$ & 1655 & - & 0.297 & -0.346 & 0.348 & -0.509 & -0.559 \\
$\mathbf{2 6}$ & 24 & 376 & 0.308 & -0.320 & 0.374 & -0.470 & -0.538 \\
$\mathbf{2 7}$ & 245 & 1427 & 0.333 & -0.315 & 0.387 & -0.494 & -0.448 \\
$\mathbf{2 8}$ & 5 & 24 & 0.310 & -0.232 & 0.365 & -0.464 & -0.479 \\
$\mathbf{2 9}$ & 5 & 49 & 0.312 & -0.284 & 0.367 & -0.479 & -0.539 \\
$\mathbf{3 0}$ & 234 & 1363 & 0.335 & -0.346 & 0.375 & -0.421 & -0.455 \\
$\mathbf{3 1}$ & 215 & 1380 & 0.332 & -0.335 & 0.397 & -0.453 & -0.462 \\
\hline
\end{tabular}

The linear regression analysis, which correlated the antibacterial activity with the atomic charges in the BZS derivatives containing a variety of substituents at positions 4,5 and 7 of the benzimidazole ring $(\mathrm{n}=12)$, showed that the best correlation between charge and antibacterial activity occurred between the qN3 and the $-\log$ MIC in B. subtilis and MRSA, with $r>0.6$ (Table 4).

Table 4. Correlation coefficients (r) for the linear regression analysis of atomic charges with antimicrobial activity of BZS derivatives. $-\log \mathrm{MIC}=\mathrm{a}+\mathrm{bq}_{\mathrm{k}}$.

\begin{tabular}{lcccccc}
\hline Bacteria & N & q H1 & q N3 & q H1’ & q O2’ & q O3’ \\
\hline MIC & $12^{\mathrm{a}}$ & 0.332 & 0.651 & 0.596 & 0.591 & 0.270 \\
B. subtilis & $7^{\mathrm{b}}$ & 0.916 & 0.747 & 0.888 & 0.956 & 0.337 \\
& $9^{\mathrm{c}}$ & 0.889 & -0.049 & 0.808 & 0.607 & 0.814 \\
\hline MIC & $12^{\mathrm{a}}$ & -0.126 & 0.691 & 0.296 & 0.361 & -0.039 \\
MRSA & $6^{\mathrm{d}}$ & 0.938 & 0.882 & 0.798 & 0.868 & 0.530 \\
& $7^{\mathrm{e}}$ & 0.579 & -0.048 & 0.487 & 0.232 & 0.446 \\
\hline
\end{tabular}

$\mathrm{n}=$ number of compounds. ${ }^{\mathrm{a}} \mathrm{BZS}: \mathbf{1 6}, \mathbf{1 7}, \mathbf{2 0}, \mathbf{2 1}, 24-31 ;{ }^{\mathrm{b}} \mathrm{BZS}: \mathbf{1 6}, \mathbf{1 7}, \mathbf{2 0}, \mathbf{2 1}, 26,28,29$; $^{\mathrm{c}} \mathrm{BZS}$ :

16, 17, 20, 21, 24, 25, 27, 30, 31 ; ${ }^{\mathrm{d}} \mathrm{BZS}$ : 16, 17, 20, 26, 28, 29; ${ }^{\mathrm{e}} \mathrm{BZS}$ : 16, 17, 20, 24, 27, 30, 31.

In general, the parameters showed a high co-linearity with a correlation coefficient of $r>0.8$ if the linear regression was performed by splitting the compounds into two groups: the first group comprised BZS with substituents in the 4 and 5 positions, and the second group comprised BZS with substituents in the 5 and 7 positions. This method yielded the best $r$ values between qH1, qH1', qO2', and the $-\log$ MIC in B. subtilis, and between qH1, qN3, qO2', and the $-\log \mathrm{MIC}$ in MRSA, both for the BZS substituent positions 4 and 5 .

The best correlation models for the BZS derivatives that showed the greatest antibacterial activity are described in Equations 1-8 (Table 5) along with the statistical parameters for the linear regression analysis. The overall quality of the models was assessed by the correlation coefficient, $r$, the squared correlation, $r^{2}$, the standard error, $S$, and the Fisher ratio, $F$. 
Table 5. Linear regression analysis and quality of correlation for modeling the antimicrobial activity of BZS. $-\log \mathrm{MIC}=\mathrm{a}+\mathrm{bq}_{\mathrm{k}}$.

\begin{tabular}{lllllll}
\hline Eq & QSAR Model (-log MIC=) & $\boldsymbol{n}$ & $\boldsymbol{r}$ & $\boldsymbol{r}^{2}$ & $\boldsymbol{F}$ & $\boldsymbol{S}$ \\
\hline & B. subtilis & & & & & \\
1 & $-94.5331+301.216 \mathrm{qH} 1$ & 7 & 0.916 & 0.840 & 26.20 & 0.545 \\
2 & $6.07449+27.504 \mathrm{qN} 3$ & 7 & 0.747 & 0.558 & 6.31 & 0.905 \\
3 & $-19.6851+50.298 \mathrm{qH} 1$ & 7 & 0.888 & 0.788 & 18.57 & 0.599 \\
4 & $17.0515+38.3147 \mathrm{O} 2$ & 7 & 0.956 & 0.914 & 53.31 & 0.398 \\
& MRSA & & & & & \\
5 & $-77.1726+242.811 \mathrm{qH} 1$ & 6 & 0.938 & 0.880 & 29.40 & 0.321 \\
6 & $3.63887+20.752 \mathrm{qN} 3$ & 6 & 0.882 & 0.778 & 14.05 & 0.436 \\
7 & $-12.128+27.5796 \mathrm{qH} 1$ & 6 & 0.798 & 0.637 & 7.02 & 0.559 \\
8 & $8.95649+23.0719 \mathrm{qO} 2$ & 6 & 0.868 & 0.754 & 12.27 & 0.460 \\
\hline \multicolumn{6}{c}{$\mathrm{n}=$ number of compounds. }
\end{tabular}

The results suggested that the higher charges on $\mathrm{H} 1$ and $\mathrm{H} 1$ ' in conjunction the lower charges on $\mathrm{N} 3$ and $\mathrm{O} 2$ promoted the activity of BZS derivatives against $B$. subtilis and MRSA.

\section{Experimental}

\subsection{General}

Melting points were determined using a Mel-Temp melting point apparatus in open capillary tubes and are uncorrected. IR spectra were collected on a Nexus 470 FT-IR spectrophotometer. ${ }^{1} \mathrm{H}-\mathrm{NMR}$ spectra were recorded on Varian Gemini-200 MHz and Eclipse $300 \mathrm{MHz}$ JEOL spectrometers in deuterated dimethyl sulfoxide $\left(\mathrm{DMSO}^{-} \mathrm{d}_{6}\right)$ solutions using an internal TMS standard $(0 \mathrm{ppm})$. The chemical shifts are reported in parts per million $(\delta / \mathrm{ppm})$. The peak patterns are indicated as follows: $\mathrm{s}$, singlet; d, doublet; t, triplet; q, quartet; m, multiplet; br, broad. The coupling constants $(J)$ are reported in Hertz (Hz). Mass spectra were detected by electronic impact (EI) and recorded using a JEOL JEMAX505HA spectrometer by electronic impact (EI) of lower resolution at $70 \mathrm{eV}$. Flash column chromatography was carried out using silica gel 60 (230-400 mesh ASTM) from Merck.

\subsection{General procedure for preparing benzimidazolamine (10-13)}

A mixture of $\mathrm{R}_{3}$-nitroaniline 1-4 $(13.06 \mathrm{mmol})$ and tin (II) chloride dihydrate $(58.77 \mathrm{mmol}$ for every nitro group) in acetic acid $(20 \mathrm{~mL})$ was heated under reflux for $4 \mathrm{~h}$. The excess acetic acid was removed under reduced pressure, and the crude product was dissolved in 10\% hydrochloric acid. The reaction mixture was heated under reflux for $1 \mathrm{~h}$, was made alkaline by $\mathrm{NaOH}$ addition, and was extracted with ethyl acetate. The organic layer was dried over $\mathrm{Na}_{2} \mathrm{SO}_{4}$, and the solvent was evaporated under reduced pressure to given a crude product, which was purified by flash column chromatography on silica gel, using ethyl acetate:ethanol (90:10) as the eluent.

2-Methyl-1H-benzimidazol-6-amine (10). Yield: 84\%; m.p. 86-88 ${ }^{\circ} \mathrm{C}$. FT-IR $\left(\mathrm{KBr}, \mathrm{cm}^{-1}\right)$ : $3399(\mathrm{~N}-\mathrm{H})$, $3299(\mathrm{~N}-\mathrm{H}), 1639\left(\mathrm{C}=\mathrm{N}\right.$, imidazole). ${ }^{1} \mathrm{H}-\mathrm{NMR}(200 \mathrm{MHz}): \delta 2.37\left(\mathrm{~s}, 3 \mathrm{H}, \mathrm{CH}_{3}\right), 3.45$ (s br, 2H, $\mathrm{NH}_{2}$ 
exchangeable with $\left.\mathrm{D}_{2} \mathrm{O}\right), 6.43(\mathrm{dd}, 1 \mathrm{H}, \mathrm{Ar}-\mathrm{H}, J=7.7 \mathrm{~Hz}), 6.59(\mathrm{~d}, 1 \mathrm{H}, \mathrm{Ar}-\mathrm{H}, J=1.8 \mathrm{~Hz}), 7.11(\mathrm{~d}, 1 \mathrm{H}$, Ar-H, $J=8.2$ Hz). MS, m/z (Rel. Int.): 147 (M+,100), 119(8), 105 (12), 79 (13), 52 (13).

5-Fluoro-2-methyl-1H-benzimidazol-6-amine (11). Yield: 72\%; m.p. $157-158^{\circ} \mathrm{C}$. FT-IR $\left(\mathrm{KBr}, \mathrm{cm}^{-1}\right)$ : $3417(\mathrm{~N}-\mathrm{H}), 3371(\mathrm{~N}-\mathrm{H}), 1645\left(\mathrm{C}=\mathrm{N}\right.$, imidazole). ${ }^{1} \mathrm{H}-\mathrm{NMR}(300 \mathrm{MHz}): \delta 2.36\left(\mathrm{~s}, 3 \mathrm{H}, \mathrm{CH}_{3}\right), 4.69(\mathrm{~s}$ br, $2 \mathrm{H}, \mathrm{NH}_{2}$ exchangeable with $\left.\mathrm{D}_{2} \mathrm{O}\right), 6.76(\mathrm{~d}, 1 \mathrm{H}, \mathrm{Ar}-\mathrm{H}, J=8.1 \mathrm{~Hz}), 7.08(\mathrm{~d}, 1 \mathrm{H}, \mathrm{Ar}-\mathrm{H}, J=11.4 \mathrm{~Hz})$. MS, m/z (Rel. Int.): 165 (M+, 100), 137(5), 124(6), 97(9), 83 (7).

4-Bromo-2-methyl-1H-benzimidazol-6-amine (12). Yield: 66\%; oil. FT-IR (KBr, cm $\left.{ }^{-1}\right)$ : $3379(\mathrm{~N}-\mathrm{H})$, $3338(\mathrm{~N}-\mathrm{H}), 1633\left(\mathrm{C}=\mathrm{N}\right.$, imidazole). ${ }^{1} \mathrm{H}-\mathrm{NMR}(200 \mathrm{MHz}): \delta 2.38\left(\mathrm{~s}, 3 \mathrm{H}, \mathrm{CH}_{3}\right), 4.99\left(\mathrm{~s}\right.$ br, $2 \mathrm{H}, \mathrm{NH}_{2}$ exchangeable with $\left.\mathrm{D}_{2} \mathrm{O}\right), 6.54(\mathrm{~d}, 1 \mathrm{H}, \mathrm{Ar}-\mathrm{H}, J=1.6 \mathrm{~Hz}), 6.65$, (d, $\left.1 \mathrm{H}, \mathrm{Ar}-\mathrm{H}, J=1.8 \mathrm{~Hz}\right), 11.87$ (s br, $1 \mathrm{H}, \mathrm{N}-\mathrm{H}$ exchangeable with $\left.\mathrm{D}_{2} \mathrm{O}\right)$. MS, m/z (Rel. Int.): 225 (M+,100), 146 (19), 119 (9), 77 (10), 52 (7).

4-Chloro-2-methyl-1H-benzimidazol-6-amine (13). Yield: 69\%; oil. FT-IR (KBr, cm $\left.{ }^{-1}\right)$ : $3338(\mathrm{~N}-\mathrm{H})$, $3391(\mathrm{~N}-\mathrm{H}), 1637\left(\mathrm{C}=\mathrm{N}\right.$, imidazole). ${ }^{1} \mathrm{H}-\mathrm{NMR}(200 \mathrm{MHz}): \delta 2.38\left(\mathrm{~s}, 3 \mathrm{H}, \mathrm{CH}_{3}\right), 5.07$ (s br, 2H, $\mathrm{NH}_{2}$ exchangeable with $\left.\mathrm{D}_{2} \mathrm{O}\right), 6.5(\mathrm{~s}, 2 \mathrm{H}, \mathrm{Ar}-\mathrm{H}), 11.84$ (s br, $1 \mathrm{H}, \mathrm{N}-\mathrm{H}$ exchangeable with $\left.\mathrm{D}_{2} \mathrm{O}\right) . \mathrm{MS}, \mathrm{m} / \mathrm{z}$ (Rel. Int.): 181 (M+,100), 146 (13), 105(5), 78(11), 52 (5).

\subsection{Procedure for preparing 5-chloro-2-methyl-1H-benzimidazol-6-amine (14)}

To a suspension of 4-chloro-2-nitroaniline $(4.7 \mathrm{mmol})$ in acetic acid $(14.0 \mathrm{~mL})$, was added tin (II) chloride dihydrate $(0.021 \mathrm{mmol})$. The mixture was heated under reflux for $4 \mathrm{~h}$. To the reaction solution was added $\mathrm{NaHCO}_{3}$ followed by extraction with ethyl acetate. The organic layers were dried over $\mathrm{Na}_{2} \mathrm{SO}_{4}$ and removed by evaporation under vacuum. The pure benzimidazole 8 was obtained in $74 \%$ yield.

To the benzimidazole $8(1.8 \mathrm{mmol})$ was added a mixture of $\mathrm{H}_{2} \mathrm{SO}_{4} / \mathrm{HNO}_{3}(3: 1,1.2 \mathrm{~mL})$. The reaction was stirred at room temperature for $1 \mathrm{~h}$. To the mixture was added cold water. The resulting solid was filtered, washed with cold water, and dried under vacuum to afford pure benzimidazole 9 in $98 \%$ yield.

To a suspension of benzimidazole $9(1.8 \mathrm{mmol})$ in $\mathrm{HCl}(5 \mathrm{~mL})$ was added tin (II) chloride dihydrate $(8.0 \mathrm{mmol})$. The mixture was heated under reflux for $4 \mathrm{~h}$. The resulting solid was filtered, dissolved in aqueous $10 \% \mathrm{NaOH}$ and the product extracted with ethyl acetate. The extract was dried and under vacuum to gave the desired benzimidazolamine 14. Yield: $78 \%$; m.p. $108{ }^{\circ} \mathrm{C}$. FT-IR $\left(\mathrm{KBr}, \mathrm{cm}^{-1}\right): 3429$ $(\mathrm{N}-\mathrm{H}), 3354(\mathrm{~N}-\mathrm{H}), 1639\left(\mathrm{C}=\mathrm{N}\right.$, imidazole). ${ }^{1} \mathrm{H}-\mathrm{NMR}(200 \mathrm{MHz}): \delta 2.40\left(\mathrm{~s}, 3 \mathrm{H}, \mathrm{CH}_{3}\right), 4.94(\mathrm{~s}$ br, 2H, $\mathrm{NH}_{2}$ exchangeable with $\left.\mathrm{D}_{2} \mathrm{O}\right), 6.85$ (s, $\left.1 \mathrm{H}, \mathrm{Ar}-\mathrm{H}\right), 7.32$ (s, 1H, Ar-H). MS, m/z (Rel. Int.): 181 (M+, 100), 146 (11), 105(4), 78(11), 52 (8).

\subsection{Procedure for preparing 2-methyl-5-methoxy-1H-benzimidazol-6-amine (15)}

To 2-methoxy-4-nitroaniline $5(29.8 \mathrm{mmol})$ was added acetic anhydride $(9.2 \mathrm{~mL})$ and acetic acid $(11.0 \mathrm{~mL})$. The reaction was stirred under reflux for $2 \mathrm{~h}$. To the mixture was added cold water, and the resulting solid was filtered, washed with cold water, and dried under vacuum. To this solid was added fuming $\mathrm{HNO}_{3}(12.0 \mathrm{~mL})$, the reaction was stirred at 0 to $5{ }^{\circ} \mathrm{C}$ for $1 \mathrm{~h}$. To the mixture was added cold 
water, and the resulting solid was filtered, washed with cold water, and dried under vacuum, to afford the pure acetamide 6 in 77\% yield. From the acetamide 6, the benzimidazolamine 15 was obtained following the general procedure for preparing benzimidazolamines 10-13. Yield: 54\%; oil. FT-IR $\left(\mathrm{KBr}, \mathrm{cm}^{-1}\right): 3417(\mathrm{~N}-\mathrm{H}), 3342(\mathrm{~N}-\mathrm{H}), 1637\left(\mathrm{C}=\mathrm{N}\right.$, imidazole), $1140\left(\mathrm{O}-\mathrm{CH}_{3}\right) .{ }^{1} \mathrm{H}-\mathrm{NMR}(200 \mathrm{MHz}): \delta$ $2.36\left(\mathrm{~s}, 3 \mathrm{H}, \mathrm{CH}_{3}\right), 3.76\left(\mathrm{~s}, 3 \mathrm{H}, \mathrm{O}-\mathrm{CH}_{3}\right), 4.4$ (s br, $2 \mathrm{H}, \mathrm{NH}_{2}$ exchangeable with $\left.\mathrm{D}_{2} \mathrm{O}\right), 6.68(\mathrm{~s}, 1 \mathrm{H}, \mathrm{Ar}-$ H), 6.86 (s, 1H, Ar-H). MS, m/z (Rel. Int.): 177 (M+, 100), 162 (78), 134 (37), 89 (6), 52 (4).

\subsection{General procedure for preparing benzimidazolylbenzenesulfonamides 16-23}

To a solution of benzimidazolamine $(\mathbf{1 0 - 1 5}, 6.8 \mathrm{mmol})$ and pyridine $(6.8 \mathrm{mmol}, 0.55 \mathrm{~mL})$ in anhydrous acetone was added benzenesulfonyl chloride $(6.8 \mathrm{mmol}, 0.87 \mathrm{~mL})$. The reaction mixture was stirred at room temperature under a $\mathrm{N}_{2}$ atmosphere for $24 \mathrm{~h}$. Aqueous $\mathrm{NaHCO}_{3}$ was then added, and the mixture was extracted with ethyl acetate. The organic layer was dried over $\mathrm{Na}_{2} \mathrm{SO}_{4}$, filtered, concentrated, and purified by flash column chromatography on silica gel (gradient elution 50:50 hexane/ethyl acetate to 70:30 ethyl acetate/ethanol) to give 16-21 and 22-23.

N-(2-methyl-1H-benzimidazol-6-yl)benzenesulfonamide (16). Yield: 68\%; m.p. 221-222 ${ }^{\circ} \mathrm{C}$. FT-IR $\left(\mathrm{KBr}, \mathrm{cm}^{-1}\right): 3302(\mathrm{~N}-\mathrm{H}), 1633(\mathrm{C}=\mathrm{N}$, imidazole $), 1340$ and $1155\left(\mathrm{O}_{2} \mathrm{~S}-\mathrm{NH}\right) .{ }^{1} \mathrm{H}-\mathrm{NMR}(300 \mathrm{MHz}): \delta$ $2.41\left(\mathrm{~s}, 3 \mathrm{H}, \mathrm{CH}_{3}\right), 6.83$ (d, 1H, Ar-H, J = $\left.7.9 \mathrm{~Hz}\right), 7.14$ (s, 1H, Ar-H), 7.5 (dd, 1H, Ar-H, J=6 Hz), 7.54 (m, 3H, Ar-H), 7.68 (dd, 2H, Ar-H, $J=7.8$ Hz). MS, m/z (Rel. Int.): 287 (M+, 36), 146 (100), 119 (7), 105 (4), 77 (5).

$\mathrm{N}$-(5-fluoro-2-methyl-1H-benzimidazol-6-yl)benzenesulfonamide (17). Yield: $45 \%$; m.p. $152{ }^{\circ} \mathrm{C}$. FT-IR $\left(\mathrm{KBr}, \mathrm{cm}^{-1}\right): 3253(\mathrm{~N}-\mathrm{H}), 1635(\mathrm{C}=\mathrm{N}$, imidazole $), 1323$ and $1167\left(\mathrm{O}_{2} \mathrm{~S}-\mathrm{NH}\right) .{ }^{1} \mathrm{H}-\mathrm{NMR}(200 \mathrm{MHz}): \delta$ 2.43 (s, 3H, $\left.\mathrm{CH}_{3}\right), 7.17$ (d, 1H, Ar-H, J=10.2 Hz), 7.17 (d, 2H, Ar-H, J=7.0 Hz), 7.57 (m, 5H, Ar$\mathrm{H}), 9.91$ (s br, $1 \mathrm{H}, \mathrm{NH}$ exchangeable with $\mathrm{D}_{2} \mathrm{O}$ ), 12.27 (s br, $1 \mathrm{H}, \mathrm{NH}$ exchangeable with $\mathrm{D}_{2} \mathrm{O}$ ). MS, m/z (Rel. Int.): 305 (M+, 18), 164 (100), 137 (12), 96 (7), 77 (11).

N-(4-bromo-2-methyl-1H-benzimidazol-6-yl)benzenesulfonamide (18). Yield: 66\%; m.p. 272-273 ${ }^{\circ} \mathrm{C}$. FT-IR $\left(\mathrm{KBr}, \mathrm{cm}^{-1}\right): 3290(\mathrm{~N}-\mathrm{H}), 1631\left(\mathrm{C}=\mathrm{N}\right.$, imidazole), 1317 and $1163\left(\mathrm{O}_{2} \mathrm{~S}-\mathrm{NH}\right) .{ }^{1} \mathrm{H}-\mathrm{NMR}(200 \mathrm{MHz})$ : $\delta 2.43\left(\mathrm{~s}, 3 \mathrm{H}, \mathrm{CH}_{3}\right), 7.02(\mathrm{~d}, 1 \mathrm{H}, \mathrm{Ar}-\mathrm{H}, J=1.8 \mathrm{~Hz}), 7.15$ (d, 1H, Ar-H, J=2.0 Hz), 7.53 (m, 3H, ArH), 7.69 (dd, 2H, Ar-H, J=8.2 Hz), 10.19 (s, 1H, NH exchangeable with $\mathrm{D}_{2} \mathrm{O}$ ), 12.45 (s br, 1H, NH exchangeable with $\left.\mathrm{D}_{2} \mathrm{O}\right)$. MS, m/z (Rel. Int.): 365 (M+, 27), 224 (100), 145 (14), 104 (5), 77 (17).

N-(4-chloro-2-methyl-1H-benzimidazol-6-yl)benzenesulfonamide (19). Yield: 57\%; m.p. $358{ }^{\circ} \mathrm{C}$. FTIR $\left(\mathrm{KBr}, \mathrm{cm}^{-1}\right): 3284(\mathrm{~N}-\mathrm{H}), 1633(\mathrm{C}=\mathrm{N}$, imidazole $), 1319$ and $1162\left(\mathrm{O}_{2} \mathrm{~S}-\mathrm{NH}\right) .{ }^{1} \mathrm{H}-\mathrm{NMR}(200 \mathrm{MHz})$ : $\delta 2.43\left(\mathrm{~s}, 3 \mathrm{H}, \mathrm{CH}_{3}\right), 6.89$ (d, 1H, Ar-H, J=1.6 Hz), 7.11 (d, 1H, Ar-H, J=1.8 Hz), 7.53 (m, 3H), 7.70 (dd, 2H, Ar-H, $J=7.9 \mathrm{~Hz}), 10.2\left(\mathrm{~s}, 1 \mathrm{H}, \mathrm{NH}\right.$ exchangeable with $\left.\mathrm{D}_{2} \mathrm{O}\right), 12.41$ (s br, $1 \mathrm{H}, \mathrm{NH}$ exchangeable with $\mathrm{D}_{2} \mathrm{O}$ ). MS, m/z (Rel. Int.): 321 (M+, 26) 180 (100), 153 (6), 103 (2), 77 (8).

$\mathrm{N}$-(5-chloro-2-methyl-1H-benzimidazol-6-yl)benzenesulfonamide (20). Yield: 53\%; m.p. $224{ }^{\circ} \mathrm{C}$. FTIR $\left(\mathrm{KBr}, \mathrm{cm}^{-1}\right): 3275(\mathrm{~N}-\mathrm{H}), 1631(\mathrm{C}=\mathrm{N}$, imidazole $), 1292$ and $1151\left(\mathrm{O}_{2} \mathrm{~S}-\mathrm{NH}\right) .{ }^{1} \mathrm{H}-\mathrm{NMR}(200 \mathrm{MHz})$ : 
$\delta 2.45\left(\mathrm{~s}, 3 \mathrm{H}, \mathrm{CH}_{3}\right), 7.20(\mathrm{~s}, 1 \mathrm{H}, \mathrm{Ar}-\mathrm{H}), 7.46(\mathrm{~s}, 1 \mathrm{H}, \mathrm{Ar}-\mathrm{H}), 7.6(\mathrm{~m}, 5 \mathrm{H}, \mathrm{Ar}-\mathrm{H}), 9.82$ (s br, 1H, NH exchangeable with $\left.\mathrm{D}_{2} \mathrm{O}\right), 12.36$ ( $\mathrm{s}$ br, $1 \mathrm{H}, \mathrm{NH}$ exchangeable with $\left.\mathrm{D}_{2} \mathrm{O}\right) . \mathrm{MS}, \mathrm{m} / \mathrm{z}$ (Rel. Int.): $321(\mathrm{M}+$, 20), 180 (100), 153 (7), 103 (2), 77 (7).

N-(2-methyl-5-methoxi-1H-benzimidazol-6-yl)benzenesulfonamide (21). Yield: 22\%; m.p. 206-207 ${ }^{\circ} \mathrm{C}$. FT-IR $\left(\mathrm{KBr}, \mathrm{cm}^{-1}\right): 3282(\mathrm{~N}-\mathrm{H}), 1633\left(\mathrm{C}=\mathrm{N}\right.$, imidazole), 1325 and $1167\left(\mathrm{O}_{2} \mathrm{~S}-\mathrm{NH}\right) .{ }^{1} \mathrm{H}-\mathrm{NMR}$ (300 MHz): $\delta 2.42\left(\mathrm{~s}, 3 \mathrm{H}, \mathrm{CH}_{3}\right), 3.38\left(\mathrm{~s}, 3 \mathrm{H}, \mathrm{O}-\mathrm{CH}_{3}\right), 6.86(\mathrm{~s}, 1 \mathrm{H}, \mathrm{Ar}-\mathrm{H}), 7.26(\mathrm{~s}, 1 \mathrm{H}, \mathrm{Ar}-\mathrm{H}), 7.47$ (m, $2 \mathrm{H}, \mathrm{Ar}-\mathrm{H}, J=7.6 \mathrm{~Hz}), 7.57$ (m, 1H, Ar-H, $J=7.3 \mathrm{~Hz}), 7.61(\mathrm{dd}, 2 \mathrm{H}, \mathrm{Ar}-\mathrm{H}, J=7.8 \mathrm{~Hz}), 9.30$ (s, $1 \mathrm{H}$, $\mathrm{NH}$ exchangeable with $\mathrm{D}_{2} \mathrm{O}$ ), 12.06 ( $\mathrm{s}$ br, $1 \mathrm{H}, \mathrm{NH}$ exchangeable with $\mathrm{D}_{2} \mathrm{O}$ ). MS, m/z (Rel. Int.): 317 (36), 176 (100), 148 (32), 107 (6), 77 (7).

N-(2-methyl-1-phenylsulfonyl-1H-benzimidazol-6-yl)benzenesulfonamide (22). Yield: 2\%; m.p. 146-148 ${ }^{\circ} \mathrm{C}$. FT-IR (KBr, cm $\left.{ }^{-1}\right): 3427(\mathrm{~N}-\mathrm{H}), 1622\left(\mathrm{C}=\mathrm{N}\right.$, imidazole), $1163\left(\mathrm{O}_{2} \mathrm{~S}-\mathrm{NH}\right) .{ }^{1} \mathrm{H}-\mathrm{NMR}(300 \mathrm{MHz}): \delta 2.76$ $\left(\mathrm{s}, 3 \mathrm{H}, \mathrm{CH}_{3}\right), 7.23$ (dd, $\left.J=8.8 \mathrm{~Hz}\right), 7.14$ (dd, $\left.J=8.8 \mathrm{~Hz}\right), 7.07$ (dd, 1H, $\left.J=8.7 \mathrm{~Hz}\right), 10.12(\mathrm{~s}, 1 \mathrm{H}, \mathrm{NH}$ exchangeable with $\mathrm{D}_{2} \mathrm{O}$ ). MS, m/z (Rel. Int.): 427 (M+, 52), 286 (100), 141 (41), 97 (6), 77 (45).

N-(2-methyl-5-methoxi-1-phenylsolfonyl-1H-benzimidazol-6-yl)benzenesulfonamide (23). Yield: 15\%; m.p. 186-187 ${ }^{\circ} \mathrm{C}$. FT-IR (KBr, cm $\left.{ }^{-1}\right): 3261(\mathrm{~N}-\mathrm{H}), 1601\left(\mathrm{C}=\mathrm{N}\right.$, imidazole), and $1176\left(\mathrm{O}_{2} \mathrm{~S}-\mathrm{NH}\right), 1091$ (O-CH3). ${ }^{1} \mathrm{H}-\mathrm{NMR}(200 \mathrm{MHz}): \delta 2.73\left(\mathrm{~s}, 3 \mathrm{H}, \mathrm{CH}_{3}\right), 3.48(\mathrm{~s}, 3 \mathrm{H}), 7.09(\mathrm{~s}, 1 \mathrm{H}), 7.49(\mathrm{~m}, 2 \mathrm{H}, J=7 \mathrm{~Hz})$, $7.63(\mathrm{~m}, 5 \mathrm{H}), 7.78(\mathrm{~m}, 1 \mathrm{H}, J=7.6 \mathrm{~Hz}), 7.81(\mathrm{~s}, 1 \mathrm{H}), 7.91(\mathrm{dd}, 2 \mathrm{H}, J=8.2 \mathrm{~Hz}), 9.73(\mathrm{~s} .1 \mathrm{H}, \mathrm{NH}$ exchangeable with $\mathrm{D}_{2} \mathrm{O}$ ). MS, m/z (Rel. Int.): 457 (M+, 20), 316 (100), 175 (19), 141 (26), 77 (98).

\subsection{General procedure for the synthesis of benzimidazolylbenzenesulfonamides $\mathbf{2 4 , 2 6 - 3 1}$}

To benzimidazolylbenzenesulfonamide (16-21, $3.5 \mathrm{mmol})$ was added fuming $\mathrm{HNO}_{3}(2.0 \mathrm{~mL})$. The reaction mixture was stirred at $0-5{ }^{\circ} \mathrm{C}$ for $1 \mathrm{~h}$. Cool water was then added to provide a yellow solid. The solid was filtered, washed twice with water and dried. The mixture of $\mathbf{2 4}$ and $\mathbf{2 6}$ was purified by flash column chromatography on silica gel, using gradient elution, 75:25 to 55:45 hexane/ethyl acetate.

N-(2-methyl-7-nitro-1H-benzimidazol-6-yl)benzenesulfonamide (24). Yield: 76\%; m.p. $182{ }^{\circ} \mathrm{C}$. FT-IR $\left(\mathrm{KBr}, \mathrm{cm}^{-1}\right): 3410(\mathrm{~N}-\mathrm{H}), 3222(\mathrm{~N}-\mathrm{H}), 1630(\mathrm{C}=\mathrm{N}$, imidazole $), 1493$ and $1356\left(\mathrm{NO}_{2}\right), 1311$ and 1161 $\left(\mathrm{O}_{2} \mathrm{~S}-\mathrm{NH}\right) .{ }^{1} \mathrm{H}-\mathrm{NMR}(300 \mathrm{MHz}): \delta 2.71\left(\mathrm{~s}, 3 \mathrm{H}, \mathrm{CH}_{3}\right), 7.19(\mathrm{~d}, 1 \mathrm{H}, J=8.7 \mathrm{~Hz}), 7.54(\mathrm{dd}, 2 \mathrm{H}$, $J=8.1 \mathrm{~Hz}), 7.67(\mathrm{~m}, 3 \mathrm{H}), 7.93(\mathrm{~d}, 1 \mathrm{H}, J=8.7 \mathrm{~Hz}), 10.47$ (s br, $1 \mathrm{H}, \mathrm{NH}$ exchangeable with $\left.\mathrm{D}_{2} \mathrm{O}\right)$. MS, m/z (Rel. Int.): 332 (M+, 64), 191 (100), 131 (29), 104 (12), 77 (34).

N-(2-methyl-5-nitro-1H-benzimidazol-6-yl)benzenesulfonamide (26). Yield: $22 \%$; m.p. $184{ }^{\circ} \mathrm{C}$. FT-IR $\left(\mathrm{KBr}, \mathrm{cm}^{-1}\right): 3261(\mathrm{~N}-\mathrm{H}), 1643(\mathrm{C}=\mathrm{N}$, imidazole $), 1464$ and $1358\left(\mathrm{NO}_{2}\right), 1307$ and $1174\left(\mathrm{O}_{2} \mathrm{~S}-\mathrm{NH}\right)$. ${ }^{1} \mathrm{H}-\mathrm{NMR}(200 \mathrm{MHz}): \delta 2.49\left(\mathrm{~s}, 3 \mathrm{H}, \mathrm{CH}_{3}\right), 7.13(\mathrm{~s}, 1 \mathrm{H}), 7.58(\mathrm{~m}, 5 \mathrm{H}), 8.05(\mathrm{~s}, 1 \mathrm{H}), 10.04(\mathrm{~s}$ br, 1H, NH exchangeable with $\mathrm{D}_{2} \mathrm{O}$ ), 12.72 (s br, $1 \mathrm{H}, \mathrm{NH}$ exchangeable with $\mathrm{D}_{2} \mathrm{O}$ ). MS, m/z (Rel. Int.): 332 (M+, 58), 191 (100), 131 (26), 104 (6), 77 (59). 
N-(5-fluoro-2-methyl-7-nitro-1H-benzimidazol-6-yl)benzenesulfonamide (27). Yield: 75\%; m.p. $242{ }^{\circ} \mathrm{C}$. FT-IR (KBr, cm $\left.{ }^{-1}\right): 3348(\mathrm{~N}-\mathrm{H}), 3265,1639\left(\mathrm{C}=\mathrm{N}\right.$, imidazole), $1522\left(\mathrm{NO}_{2}\right), 1325$ and 1167 $\left(\mathrm{O}_{2} \mathrm{~S}-\mathrm{NH}\right) .{ }^{1} \mathrm{H}-\mathrm{NMR}(200 \mathrm{MHz}): \delta 2.51$ (s, 3H, $\left.\mathrm{CH}_{3}\right), 7.55$ (m, 6H), 10.35 (s br, 1H, NH exchangeable with $\mathrm{D}_{2} \mathrm{O}$ ), 12.95 (s br, 1H, NH exchangeable with $\mathrm{D}_{2} \mathrm{O}$ ). MS, m/z (Rel. Int.): 350 (M+, 47), 209 (100), 192 (51), $122(8), 77$ (12).

N-(4-bromo-2-methyl-5-nitro-1H-benzimidazol-6-yl)benzenesulfonamide (28). Yield: 71\%; m.p. $251{ }^{\circ} \mathrm{C}$. FT-IR $\left(\mathrm{KBr}, \mathrm{cm}^{-1}\right): 3373(\mathrm{~N}-\mathrm{H}), 3215(\mathrm{~N}-\mathrm{H}), 1624\left(\mathrm{C}=\mathrm{N}\right.$, imidazole), $1463\left(\mathrm{NO}_{2}\right), 1309$ and $1161\left(\mathrm{O}_{2} \mathrm{~S}-\mathrm{NH}\right) .{ }^{1} \mathrm{H}-\mathrm{NMR}(300 \mathrm{MHz}): \delta 2.53\left(\mathrm{~s}, 3 \mathrm{H}, \mathrm{CH}_{3}\right), 7.13(\mathrm{~s}, 1 \mathrm{H}), 7.54(\mathrm{~m}, 2 \mathrm{H}), 7.64(\mathrm{~m}, 3 \mathrm{H})$, 10.33 ( s br, $1 \mathrm{H}, \mathrm{NH}$ exchangeable with $\mathrm{D}_{2} \mathrm{O}$ ), 13.11 ( $\mathrm{s}$ br, $1 \mathrm{H}, \mathrm{NH}$ exchangeable with $\mathrm{D}_{2} \mathrm{O}$ ). MS, m/z (Rel. Int.): 410 (M+, 92), 269 (82), 239 (21), 132 (14), 77 (34).

N-(4-chloro-2-methyl-5-nitro-1H-benzimidazol-6-yl)benzenesulfonamide (29). Yield: 92\%; m.p. 140-141 ${ }^{\circ} \mathrm{C}$. FT-IR (KBr, cm $\left.{ }^{-1}\right): 3394(\mathrm{~N}-\mathrm{H}), 3255(\mathrm{~N}-\mathrm{H}), 1624\left(\mathrm{C}=\mathrm{N}\right.$, imidazole), $1369\left(\mathrm{NO}_{2}\right), 1338$ and $1172\left(\mathrm{O}_{2} \mathrm{~S}-\mathrm{NH}\right) .{ }^{1} \mathrm{H}-\mathrm{NMR}(300 \mathrm{MHz}): \delta 2.55\left(\mathrm{~s}, 3 \mathrm{H}, \mathrm{CH}_{3}\right), 6.99(\mathrm{~s}, 1 \mathrm{H}), 7.54(\mathrm{~m}, 2 \mathrm{H}), 7.65(\mathrm{~m}$, $3 \mathrm{H}), 10.39$ (s br, 1H, NH exchangeable with $\mathrm{D}_{2} \mathrm{O}$ ). MS, m/z (Rel. Int.): 366 (M+, 100), 224 (97), 208 (33), 132 (12), 77 (37).

N-(5-chloro-2-methyl-7-nitro-1H-benzimidazol-6-yl)benzenesulfonamide (30). Yield: 67\%; m.p. 277-278 ${ }^{\circ} \mathrm{C}$. FT-IR (KBr, cm $\left.{ }^{-1}\right): 3379(\mathrm{~N}-\mathrm{H}), 3288(\mathrm{~N}-\mathrm{H}), 1631\left(\mathrm{C}=\mathrm{N}\right.$, imidazole), $1520\left(\mathrm{NO}_{2}\right), 1338$ and $1163\left(\mathrm{O}_{2} \mathrm{~S}-\mathrm{NH}\right) .{ }^{1} \mathrm{H}-\mathrm{NMR}(300 \mathrm{MHz}): \delta 2.53\left(\mathrm{~s}, 3 \mathrm{H}, \mathrm{CH}_{3}\right), 7.60(\mathrm{~m}, 5 \mathrm{H}), 7.82(\mathrm{~s}, 1 \mathrm{H}), 10.41(\mathrm{~s} b r$, $1 \mathrm{H}$, NH exchangeable with $\mathrm{D}_{2} \mathrm{O}$ ), 13.04 ( $\mathrm{s}$ br, $1 \mathrm{H}, \mathrm{NH}$ exchangeable with $\mathrm{D}_{2} \mathrm{O}$ ). MS, m/z (Rel. Int.): $366(\mathrm{M}+, 42), 224$ (100), 208 (74), 132 (13), 77 (16).

N-(5-methoxy-2-methyl-7-nitro-1H-benzimidazol-6-yl)benzenesulfonamide (31). Yield: 94\%; m.p. $182{ }^{\circ} \mathrm{C}$. FT-IR $\left(\mathrm{KBr}, \mathrm{cm}^{-1}\right): 3290(\mathrm{~N}-\mathrm{H}), 1622(\mathrm{C}=\mathrm{N}$, imidazole $), 1544\left(\mathrm{NO}_{2}\right), 1346$ and $1140\left(\mathrm{O}_{2} \mathrm{~S}-\right.$ $\mathrm{NH}) .{ }^{1} \mathrm{H}-\mathrm{NMR}(300 \mathrm{MHz}): \delta 2.65\left(\mathrm{~s}, 3 \mathrm{H}, \mathrm{CH}_{3}\right), 3.26(\mathrm{~s}, 3 \mathrm{H}), 7.35(\mathrm{~s}, 1 \mathrm{H}), 7.53(\mathrm{~m}, 5 \mathrm{H}), 10.16(\mathrm{~s} b r$, 1H, NH exchangeable with $\mathrm{D}_{2} \mathrm{O}$ ). MS, m/z (Rel. Int.): 362 (M+, 58), 221 (100), 173 (78), 133 (3), 77 (11).

\subsection{Procedure for preparing N-(7-amino-2-methyl-1H-benzimidazol-6-yl)benzenesulfonamide (25)}

A mixture of benzimidazolilbenzenesulfonamide (24, $2.9 \mathrm{mmol})$ and tin (II) chloride II dihydrate $(13.0 \mathrm{mmol})$ in ethyl acetate/ethanol 1:1 $(100 \mathrm{~mL})$ was heated under reflux for $4 \mathrm{~h}$. The solvent was removed under reduced pressure and the crude product was added to aqueous $\mathrm{NaHCO}_{3}$. The mixture was subsequently extracted with ethyl acetate. The organic layer was dried over $\mathrm{Na}_{2} \mathrm{SO}_{4}$, filtered, and concentrated to give 25. Yield: $65 \%$; m.p. $225^{\circ} \mathrm{C}$. FT-IR $\left(\mathrm{KBr}, \mathrm{cm}^{-1}\right): 3471(\mathrm{~N}-\mathrm{H}), 3319(\mathrm{~N}-\mathrm{H}), 1628$ $\left(\mathrm{C}=\mathrm{N}\right.$, imidazole), 1311 and $1159\left(\mathrm{O}_{2} \mathrm{~S}-\mathrm{NH}\right) .{ }^{1} \mathrm{H}-\mathrm{NMR}(300 \mathrm{MHz}): \delta 2.39$ (s, 3H, $\left.\mathrm{CH}_{3}\right), 4.89$ (s br, 2H, $\mathrm{NH}_{2}$ exchangeable with $\left.\mathrm{D}_{2} \mathrm{O}\right), 6.31(\mathrm{~d}, \mathrm{Ar}-\mathrm{H}, J=8.4 \mathrm{~Hz}), 6.43(\mathrm{~d}, \mathrm{Ar}-\mathrm{H}, J=8.4 \mathrm{~Hz}), 7.49(\mathrm{~m}, 2 \mathrm{H}, \mathrm{Ar}-$ $\mathrm{H}, J=7.8 \mathrm{~Hz}$ ), 7.59 (m, 1H, Ar-H, $J=7.5 \mathrm{~Hz}$ ), 7.64 (dd, 2H, Ar-H, $J=7.6 \mathrm{~Hz}$ ), 9.14 (s br, 1H, NH exchangeable with $\left.\mathrm{D}_{2} \mathrm{O}\right), 11.91\left(\mathrm{~s}\right.$ br, $1 \mathrm{H}, \mathrm{NH}$ exchangeable with $\left.\mathrm{D}_{2} \mathrm{O}\right)$. MS, m/z (Rel. Int.): $302(\mathrm{M}+$, 9), 161 (100), 134 (9), 107 (4), 77 (14). 


\section{Conclusions}

We have synthesized and evaluated the antibacterial activities of BZS analogs containing electronreleasing and electron-withdrawing substituents on the benzimidazole ring. SAR and theoretical studies of this series of compounds have shown that the antibacterial activity of BZS compounds may be related to the charges on the acidic hydrogen atoms in the BZS structure. Two compounds, 28 and 29, have shown antibacterial activity against Gram-positive bacteria, which suggests that they may be members of a promising new class of BZS anti-MRSA agents. These compounds present a good starting point for modelling antimicrobial activity. Future work will focus on calculation of the absolute gas phase acidity of the hydrogens $\mathrm{H} 1$ and H1' of BZS and a QSAR between the acidity of these hydrogens and antimicrobial activity.

\section{Acknowledgements}

This work was supported by the Consejo Nacional de Ciencia y Tecnología (CONACyT) FM grant 61626, DGAPA-PAPIIT RM project IN2049103, Programa de Mejoramiento del Profesorado scholarship and a Ph. D. Scholarship (M. M. González-Chávez) from the CONACyT. We also thank R. Patiño, A. Peña, E. Huerta, E. Hernández, L. Velasco, and J. Pérez from the Instituto de Química, for technical support.

\section{References}

1. Jones, M.E.; Blosser-Middleton, R.S.; Thornsberry, C.; Karlowsky, J.A.; Sahm, D.F. The activity of levofloxacin and other antimicrobials against clinical isolates of Streptococcus pneumoniae collected worldwide during 1999-2002. Diagn. Microbiol. Infect. Dis. 2003, 47, 579-586.

2. Fouda, S.I.; Kadry, A.A.; Shibl, A.M. Beta-lactam and macrolide resistance and serotype distribution among Streptococcus pneumoniae isolates from Saudi Arabia. J. Chemother. 2004, 16, 517-523.

3. Jenkins, S.G.; Farrell, D.J.; Patel, M.; Lavin, B.S. Trends in anti-bacterial resistance among Streptococcus pneumonia isolated in the USA, 2000-2003: PROTEK US years 1-3. J. Infect. 2005, 51, 355-363.

4. Krcméry, V.; Sefton, A. Vancomycin resistance in Gram-positive bacteria other than Enterococcus spp. Int. J. Antimicrob. Agents 2000, 14, 99-105.

5. Cuellar-Rodríguez, J.; Galindo-Fraga, A.; Guevara, V.; Pérez-Jiménez, C.; Espinosa-Aguilar, L.; Rolón, A.L.; Hernández-Cruz, A.; López-Jácome, E.; Bobadilla-del-Valle, M.; Martínez Gamboa, A.; Ponce-de-León, A.; Sifuentes-Osorio, J. Vancomycin-resistant enterococci, México City. Emerg. Infect. Dis. 2007, 13, 798-799.

6. Kaye, K.S.; Engemann, J.J.; Fraimow, H.S.; Abrutyn, E. Pathogens resistant to antimicrobial agents:epidemiology, molecular mechanisms, and clinical management. Infect. Dis. Clin. North. Am. 2004, 18, 467-511.

7. Tenover, F.C. Mechanisms of antimicrobial resistance in bacteria. Amer. J. Med. 2006, 119, S3-S10. 
8. Murthy, A.; De Angelis, G.; Pittet, D.; Schrenzel, J.; Uckay, I.; Harbarth, S. Cost-effectiveness of universal MRSA screening on admission to surgery. Clin. Microbiol. Infect. 2010, 16, 1747-1753.

9. Weidner-Well, M.A.; Ohemeng, K.A.; Nguyen, V.N.; Fraga-Spano, S.; Macielag, M.J.; Werblood, H.M.; Foleno, B.D.; Webb, G.C., Barret, J.F.; Hlasta, D.J. Amidino Benzimidazole inhibitors of bacterial two-component systems. Bioorg. Med. Chem. Lett. 2001, 11, 1545-1548.

10. Bürli, R.W.; McMinn, D.; Kaizerman, J.A.; Hu, W.; Ge, Y.; Pack, Q.; Jiang, V.; Gross, M.; Garcia, M.; Tanaka, R.; Moser, H.E. DNA binding ligands targeting drug-resistant Gram-positive bacteria. Part 1: internal benzimidazole derivatives. Bioorg. Med. Chem. Lett. 2004, 14, 1253-1257.

11. Hu, L.; Kully, M.L.; Boykin, D.W.; Abood, N. Optimization of the central linker of dicationic bisbenzimidazole anti-MRSA and anti-VRE agents. Bioorg. Med. Chem. Lett. 2009, 19, 3374-3377.

12. Zimmerman, S.; Innocenti, A.; Casini, A.; Ferry, J.G.; Scozzafava, A.; Supuran, C.T. Carbonic anhydrase inhibitors. Inhibition of the prokaryotic beta and gamma-class enzymes from Archaea with sulfonamides. Bioorg. Med. Chem. Lett. 2004, 14, 6001-6006.

13. Isik, K.; Özdemir-Kocak, F. Antimicrobial activity screening of some sulfonamides on some Nocardia species and isolates. Microbiol. Res. 2009, 164, 49-58.

14. Hauel, N.H.; Nar, H.; Priepke, H.; Ries, U.; Stassen, J.-M.; Wienen, W. Structure-based design of novel potent nonpeptide thrombin inhibitors. J. Med. Chem. 2002, 45, 1757-1766.

15. McCauley, J.A.; Theberge, C.R.; Romano, J.J.; Billings, S.B.; Anderson, K.D.; Claremon, D.A.; Freidinger, R.M.; Bednar, R.A.; Mosser, S.D.; Gaul, S.L.; Connolly, T.M.; Condra, C.L.; Xia, M.; Cunningham, M.E.; Bednar, B.; Stump, G.L.; Lynch, J.J.; Macaulay, A.; Wafford, K.A.; Koblan, K.S.; Liverton, N.J. NR2B-Selective $N$-methyl-D-aspartate antagonists: synthesis and evaluation of 5-substituted benzimidazoles. J. Med. Chem. 2004, 47, 2089-2096.

16. Schuster, D.; Maurer, E.M.; Laggner, C.; Nashev, L.G.; Wilckens, T.; Langer, T.; Odermatt. A. The discovery of new 11 $\beta$-Hydroxysteroid dehydrogenase type 1 inhibitors by common feature pharmacophore modelling and virtual screening. J. Med. Chem. 2006, 49, 3454-3466.

17. Middleton, T.; Lim, H.B.; Montgomery, D.; Rockway, T.; Tang, H.; Cheng, X.; Lu, L.; Mo, H.; Kohlbrenner, W.E.; Molla, A.; Kati, W.M. Inhibition of human immunodeficiency virus type I integrase by naphthamidines and 2-aminobenzimidazoles. Antivir. Res. 2004, 64, 35-45.

18. National Committee for Clinical Laboratory Standards. Methods for Dilution Antimicrobial Susceptibility Test for Bacteria that Grow Aerobically; Approved Standard M7-A4, 4th ed.; National Committee for Clinical Laboratory Standards: Villanova, PA, USA, 1997.

19. Frisch, M.J.; Trucks, G.W.; Schlegel, H.B.; Scuseria, G.E.; Robb, M.A.; Cheeseman, J.R.; Zakrzewski, V.G.; Montgomery, J.A., Jr.; Stratmann, R.E.; Burant, J.C.; Dapprich, S.; Millam, J.M.; Daniels, A.D.; Kudin, K.N.; Strain, M.; Farkas, C.O.; Tomasi, J.; Barone, V.; Cossi, M.; Cammi, R.; Mennucci, B.; Pomelli, C.; Adamo, C.; Clifford, S.; Ochterski, J.; Petersson, G.A.; Ayala, P.Y.; Cui, Q.; Morokuma, K.; Malick, S.K.; Rabuck, A.D.; Raghavachari, K.; Foresman, J.B.; Cioslowski, J.; Ortiz, J.V.; Baboul, A.G.; Stefanov, B.B.; Liu, G.; Liashenko, A.; Piskorz, P.; Komaromi, I.; Gomperts, R.; Martin, R.L.; Fox, D.J.; Keith, T.; Al-Laham, M.A.; Peng, C.Y.; Nanayakkara, A.; Gonzalez, C.; Challacombe, M.; Gill, P.M.W.; Johnson, B.G.; Chen, W.; Wong, M.W.; Andres, J.L.; Head-Gordon, M.; Replogle, E.S.; Pople, J.A. GAUSSIAN 03(Revision A.9); Gaussian, Inc.: Pittsburgh, PA, USA, 2003. 
20. Ören, İ.; Temiz; Ö.; Yalçin, İ.; Şener, E.; Altanlar N. Synthesis and antimicrobial activity of some novel 2,5- and/ or 6-substituted benzoxazole and benzimidzole derivatives. Eur. J. Pharm. Sci. 1998, 7, 153-160.

21. Moro, W.B.; Yang, Z.; Kane, T.A.; Zhou, Q.; Harville, S.; Brouillette, C.G.; Brouillette, W.J. SAR studie for a new class of antibacterial NAD biosynthesis inhibitors. J. Comb. Chem. 2009, 11, 617-625.

22. Romero, M.L.; Méndez, F. Is the hydrogen atomic charge representative of the acidity of parasubstituted phenols? J. Phys. Chem. A. 2003, 107, 4526-4530.

Sample Availability: Samples of the compounds 16-31 are available from the authors.

(C) 2010 by the authors; licensee MDPI, Basel, Switzerland. This article is an open access article distributed under the terms and conditions of the Creative Commons Attribution license (http://creativecommons.org/licenses/by/3.0/). 